\title{
Potential for the use of vocal individuality as a conservation research tool in two threatened Philippine hornbill species, the Visayan Hornbill and the Rufous-headed Hornbill
}

\author{
RICHARD POLICHT, MILADA PETRŮ, LUCIA LASTIMOZA and \\ LEO SUAREZ
}

\section{Summary}

This study presents the first multivariate analysis of hornbill vocalizations and the first bioacoustic study of any Philippine hornbill species. We analyzed loud calls of two Philippine hornbill species, the Rufous-headed Hornbill Aceros waldeni and the Visayan Hornbill Penelopides panini panini, to assess the possibility for their use in individual identification.

Our study showed that individuals of the two studied hornbill species can be identified on the basis of their loud calls, which means that these calls potentially contain information about the caller. Discriminant analysis classified $89 \%$ of individual Rufous-headed Hornbills and $90 \%$ of individual Visayan Hornbills correctly. The acoustic variables describing the most variation among individual Visayan Hornbills were spectral variables (second amplitude peak) and temporal variables (location of the maximum amplitude and call duration). The calls of individual Rufous-headed Hornbill were differentiated mainly by spectral variables (the fundamental and the first harmonic frequency, and additionally the upper quartile of the frequency range). Frequency parameters in Rufous-headed Hornbill calls were significantly lower than those in Visayan Hornbills. The use of acoustic monitoring of individuals as a non-invasive marking technique could help to monitor hornbill individual life history and to improve census data using capture-mark-recapture technique.

\section{Introduction}

Vocalizations that are individually distinctive, i.e. potentially characteristic of individual animals, have been described in many avian species (reviewed by Dhondt and Lambrechts 1992, Stoddard 1996). Recognition based on individually distinctive vocalizations is a prominent and functionally important aspect of signalling among animals in several contexts (Bradbury and Vehrencamp 1998). Previous research has largely focused on differences in the acoustic structure of vocalizations and vocal recognition in parent-offspring interactions (e.g. Baker 1982, Aubin and Jouventin 1998, Mathevon et al. 2003), territory defence (e.g. Galeotti and Pavan 1991, Farquhar 1993, Aubin et al. 2004, Yorzinski et al. 2006) and sexual interactions (e.g. Jouventin 1982, Charrier et al. 2001, Sung and Miller 2007). Individual variation in acoustic signals may be adaptive for several reasons. It may permit individual recognition that could help in coordinating group movement and distinguishing members of neighbouring groups from strangers (Falls 1982, Ydenberg et al. 1988, Chapman and Lefebvre 1990, Wich et al. 2002, McComb et al. 2003). Individual variation of loud calls could also indicate male quality and influence female choice (Thomas Langurs Presbytis thomasi; Steenbeek and Assink 1998) and male-male competition (Red Junglefowl Gallus gallus; Furlow et al. 1998; Thomas's Langur; Steenbeek et al. 1999; Common Loon Gavia immer; Mager et al. 2007). 
In the present study we focused on vocalizations of two species of hornbills in the West Visayas in the Philippines: the Visayan Hornbill Penelopides panini panini and the Rufous-headed Hornbill Aceros waldeni. Both species are endemic to this area and are known to occur on the islands of Panay and Negros. The remaining populations of these species are extremely small and fragmented. The Visayan Hornbill is listed as 'Endangered' (BirdLife International 2007a) while the Rufous-headed Hornbill is listed as 'Critically Endangered' (BirdLife International 2oo7b). One subspecies of the Visayan Hornbill (P. p. ticaensis) from Ticao Island, an island off Masbate is feared to be already extinct (Collar et al. 1999). Members of the genus Penelopides are probably group-territorial; based on aggression shown towards other hornbills in captivity (Kemp 1995) they defend a territory or merely an area around a nest hole. The Rufous-headed Hornbill is also a territorial bird at least during the breeding season (Kauth et al. 1998).

Although hornbills are amongst the noisiest birds (Kemp 1995), very few studies have been devoted to hornbill bioacoustics. Rainey and Zuberbühler (2007) used acoustic recordings collected during studies of primates to detect seasonal variation in the abundance of forest hornbills over 10 years. Individual distinctiveness of vocalizations has been recorded in the Helmeted Hornbill Rhinoplax vigil (Haimoff 1987). Until now, no bioacoustic study has been conducted on any of the Philippine hornbill species and only verbal descriptions of vocalizations have been documented (Ripley and Rabor 1956, Rabor 1977, Kemp 1995, Brooks et al. 1992, Kauth et al. 1998, Kennedy et al. 2000, Kemp 2001). Visayan hornbills' calls are described as a series of rapidly following notes (Ripley and Rabor 1956) or noisy, keeping up incessant notes (Rabor 1977) and nasal high-pitched notes resembling the sound of a toy trumpet (Brooks et al. 1992, Kennedy et al. 200o). Males also utter soft squeaking calls sounding like ta-rik-tik, whilst feeding the female, providing the onomatopoeic common name of Visayan Hornbills - Tarictic in the local Tagalog language (Kemp 1995, Kennedy et al. 2000). Kauth et al. (1998) identified six different types of vocalization in the Rufous-headed Hornbill. Out of these, four types of male vocalization were described - territorial call, loud and far carrying, sounding very much like the bleating of a lamb; threat call, uttered repeatedly when the male is scared or engaged in an agonistic encounter; soft croaking and babbling contact call, and a monosyllabic "krook".

Loud calls of hornbills are useful in communication in dense habitats to maintain contact, to attract the attention of flying birds, to proclaim possession of a defended area (Kemp 2001) and to signal to a predator that it has been detected (Rainey et al. 2004a,b). The aim of this study was to analyze the loud calls of the Rufous-headed Hornbill and the Visayan Hornbill to assess their potential for individual identification and to determine which combination of acoustic variables could be employed to distinguish between individual birds.

\section{Methods}

\section{Study sites and subjects}

The male vocalizations of Rufous-headed Hornbill and Visayan Hornbill were recorded at two sites in the Western Visayas, Philippines. Both sites were breeding centres for endangered animals of the Philippines, particularly those that are endemic to the West-Central Visayas faunal region. The first site was the Biodiversity Conservation Centre of the Negros Forests and Ecological Foundation, Inc. (NFEFI-BCC) in Bacolod City, which is situated on the Island. This centre holds Visayan Hornbills of Negros origin but no Rufous-headed Hornbills. The second site, the Mari-it Conservation Park is situated in the foothills of Mt. Baloy, the third highest peak on the island of Panay. In the Mari-it Conservation Park, Rufous-headed Hornbills have bred successfully in captivity for the first time. At this centre we recorded vocalizations of both species of Visayan hornbills - each originating from Panay.

All subjects were kept in captivity and were housed either in pairs or individually. Vocalizations were recorded during the months of February and March 2007. This period coincided with the time of year when courtship and breeding behaviour was observed in these captive birds (Klop et al. 2000). Some birds at the Mari-it centre were nesting at this time. 


\section{Data collection}

Vocalizations were recorded with a Marantz 671 digital recorder and Sennheiser ME 67 directional microphone (frequency response $5 \mathrm{O}-2 \mathrm{O}, 000 \mathrm{~Hz} ; 2.5 \mathrm{~dB}$ ), with $\mathrm{K} 6$ powering module (sampling rate 44.1 kHz, sample size 16 bit). The distance between the subject and the microphone ranged from 2 to $8 \mathrm{~m}$. We obtained calls from nine adult male Visayan Hornbills, five at NFEFI, Bacolod and four at Mari-it, and five adult male Rufous-headed Hornbills at Mari-it.

\section{Data analyses}

The recordings were analyzed using Avisoft SASLab Pro 4.38 (Specht 2006) software. For the detailed analysis, calls that had the lowest background noise among all the recordings available for the particular individual were selected. Only the recordings of non-overlapping calls which had a good signal to noise ratio and only one-element calls (in the case of Visayan Hornbill) were considered in the analysis.

Twelve parameters in Visayan Hornbill and 13 parameters in Rufous-headed Hornbill were measured with a combination of manual and automatic procedures. Single calls were separated manually with the help of the envelope curve and the spectrogram of the following parameters: hamming window, FFT-length 1024, frame size $100 \%$ and overlap $88 \%$. This setting provided the frequency resolution of $22 \mathrm{~Hz}$, the time resolution $5.8 \mathrm{~ms}$ and the bandwidth $28 \mathrm{~Hz}$. Consequently, temporal parameters such as duration and time distance from the start to maximum amplitude (location of the maximum amplitude) were computed automatically. One-dimensional function Amplitude spectrum (linear) was used for spectral measurements in order to describe the energy spectrum of the call. Maximum frequency, minimum frequency, bandwidth, frequency of maximal amplitude (max frequency peak measured at the mean spectrum of the entire spectrogram), fundamental frequency at the highest point of its frequency modulation (and its first harmonic frequency-measured only in Rufous-headed Hornbill), 25\%, 50\% and 75\% quartile (below this frequency is $25 \%, 50 \%$ and $75 \%$ of the total energy) were measured using the function Spectral Characteristics. Linear Prediction Coding procedure (LPC) was applied for the identification of the two major energy peaks of the smooth spectral envelope: the frequency of the first amplitude peak (LPC I) and the frequency of the second amplitude peak (LPC 2). The LPC algorithm was based on the least-square estimation technique that uses autocorrelation (Specht 2006).

Stepwise discriminant analyses (DFA) were used to reduce the number of variables that were highly correlated in order to examine differences between individuals. Firstly, the data were log transformed to improve the normality of the distribution. The following variables were used as source data for these multivariate procedures: duration, time to maximum amplitude in relation to the total call duration (location of the maximum amplitude), fundamental frequency, sum of the fundamental and first harmonic frequency (in Rufous-headed Hornbill only), frequency of maximum amplitude (peak frequency), 25\%, 50\% and $75 \%$ quartile, maximum and minimum frequency, bandwidth, inter-quartile range $(=75 \%$ quartile $-25 \%$ quartile), first amplitude peak (LPC I) and second amplitude peak (LPC 2). Only the bandwidth variable did not pass the tolerance criterion of 0.01 for DFA. From the analysis, we excluded highly mutually correlated variables (when $r>0.8$ ) (see Mitchell et al. 2006). The number of variables was less than 0.33 times the number of observations, which met the criteria set by Kazial et al. (2001). A priori probabilities of classification were set proportionally to the group sizes.

Calls of both species were randomly split half-and-half, in order to validate results of discriminant analysis. This procedure provided a training set and a test set for each species. The following classification of one half of the dataset was made, with the discriminant function derived from the other half (see Klecka 1980).

All analyses were done using STATISTICA Analysis System (Release 6.o) and considered significant when $P<0.05$. We used the Bonferroni correction factor at an alpha of 0.05 to account for the number of pairwise comparisons made to reduce the chance of type I errors. The values reported in the results represent means $\pm \mathrm{SD}$. 


\section{Results}

From the recordings obtained, we analyzed 127 calls from nine male Visayan Hornbills, 10-15 calls from each individual, and 198 calls from five male Rufous-headed Hornbills, 19-88 from each individual.

The DFA resulted in eight variables in the case of Visayan Hornbill and six variables in the case of Rufous-headed Hornbill (Table 1 ). These were used in the DFA to test the accuracy of individual identification. In the Visayan Hornbill, two temporal variables were investigated (duration and relative location of the maximum amplitude) and six spectral variables (second amplitude peak, inter-quartile range, fundamental frequency, 50\% quartile, maximum and minimum frequency). In the Rufous-headed Hornbill, one temporal variable (duration) and five spectral variables ( $75 \%$ quartile, sum of the fundamental and first harmonic frequencies, inter-quartile range, second amplitude peak and minimum frequency) were investigated.

The loud calls of Visayan Hornbills were noisy with harmonic structure, and both frequency and amplitude modulation (Figure 1 ). Calls were usually formed by a single element. Some calls contained two to three elements (Figure 2). Such calls were recorded only in a small number of individuals, so they were not included in our analysis. Loud calls of Visayan Hornbills were short, with duration of $26-140 \mathrm{~ms}$ ( $70 \pm 23 \mathrm{~ms}$; mean $\pm \mathrm{SD}$ ). The peak frequency (frequency with the maximum amplitude) ranged between $540 \mathrm{~Hz}$ and $8,090 \mathrm{~Hz}(4573.7 \pm 1344.9 \mathrm{~Hz})$. The bandwidth lay between 7,190 and $17,160 \mathrm{~Hz}(4,490.2 \pm 1,449.1 \mathrm{~Hz})$ with the minimum frequency $290-600 \mathrm{~Hz}$ $(470 \pm 55.6 \mathrm{~Hz})$ and the maximum frequency $7,660-17,650 \mathrm{~Hz}(13,525.3 \pm 2,155.0 \mathrm{~Hz})$. The loud calls of Rufous-headed Hornbills (Figure 3 ) were noisy broadband sounds, with harmonic structure and both frequency and amplitude modulation. Calls can be formed by $2-5$ prominent amplitude peaks (mean 3.2). In some cases, these peaks were separated into single elements (Figure 4). Calls were uttered singly $(n=11)$ or in sequences of $2-19$ (mean $=6.4)$ with an interval of $0.7-2.9 \mathrm{~s}$ $(1.2 \pm 0.3 \mathrm{~s})$ (Figure 4). The duration of the calls ranged from 200 to $540 \mathrm{~ms}(343 \pm 64 \mathrm{~ms}$ ). The peak frequency was between $613 \mathrm{~Hz}$ and $4,831 \mathrm{~Hz}(1,539.4 \pm 1,341.9 \mathrm{~Hz})$. The bandwidth lay between 4,336 and $13,299 \mathrm{~Hz}(8,561.3 \pm 2,004 \cdot 3 \mathrm{~Hz})$ with the minimum frequency $188-357 \mathrm{~Hz}$ $(288.3 \pm 37.1 \mathrm{~Hz})$ and the maximum frequency $4,600-13,638 \mathrm{~Hz}(8,850.2 \pm 1,999.2 \mathrm{~Hz})$.

Table 1. Ranking of the variables that contributed most to DFA on individual identity of Visayan Hornbill (VisH) and Rufous-headed Hornbill (RufH), ranked from highest contribution to the lowest contribution and the correlations of individual factors with significant canonical roots.

\begin{tabular}{|c|c|c|c|c|c|c|}
\hline \multirow[t]{2}{*}{ Variable } & \multirow{2}{*}{$\begin{array}{l}\text { VisH } \\
\text { Rank }\end{array}$} & \multirow{2}{*}{$\begin{array}{l}\text { RufH } \\
\text { Rank }\end{array}$} & \multicolumn{2}{|l|}{ VisH } & \multicolumn{2}{|l|}{ RufH } \\
\hline & & & Root 1 & Root 2 & Root 1 & Root 2 \\
\hline 2LPC & 1 & 4 & -0.79 & -0.27 & -0.02 & 0.49 \\
\hline duration & 2 & 5 & -0.45 & 0.46 & -0.10 & -0.04 \\
\hline location peak & 3 & & 0.01 & -0.58 & & \\
\hline $75^{-25}$ quart & 4 & 3 & -0.12 & 0.20 & 0.47 & -0.07 \\
\hline $\mathrm{F}_{\mathrm{o}}$ & 5 & & 0.03 & -0.18 & & \\
\hline $\mathrm{F}_{\mathrm{o}}+\mathrm{H}_{\mathrm{I}}$ & & 2 & & & 0.65 & -0.12 \\
\hline quartile $50 \%$ & 6 & & -0.23 & -0.24 & & \\
\hline quartile $75 \%$ & & 1 & & & 0.55 & 0.71 \\
\hline $\mathrm{F} \max$ & 7 & & -0.28 & 0.07 & & \\
\hline $\mathrm{F} \min$ & 8 & 6 & 0.08 & -0.40 & 0.28 & -0.15 \\
\hline
\end{tabular}

Code: 2 LPC (second amplitude peak), duration (call duration; element duration in Rufous-headed Hornbill), location peak (location of the maximum amplitude), 75-25 quart (inter quartile range), $\mathrm{F}_{\mathrm{o}}$ (fundamental frequency), quartile $50 \%$ (below this frequency is $50 \%$ of the total energy), quartile $75 \%$ (below this frequency is $75 \%$ of the total energy), F max (maximum frequency), F min (minimum frequency), $\mathrm{F}_{\mathrm{o}}+\mathrm{H}_{1}$ (sum of the fundamental and first harmonic frequency). 


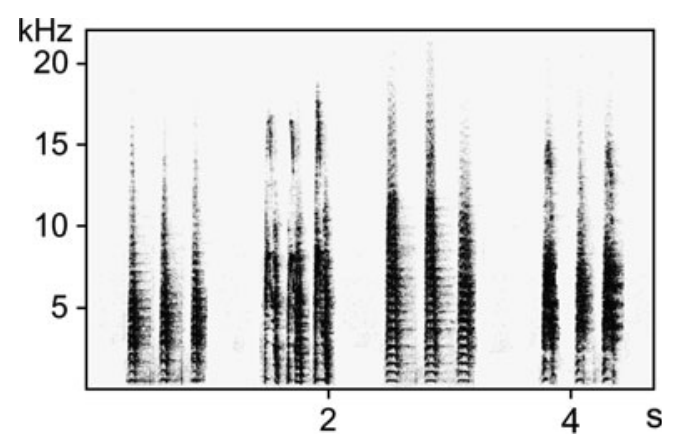

Figure 1 . Spectrogram of Visayan Hornbill calls from four individual males, three calls from each of the four individuals (the intervals between calls were modified).

Most of the frequency parameters of Rufous-headed Hornbill (fundamental frequency, frequency of maximum amplitude, $25 \%, 50 \%$ and $75 \%$ quartile, minimum and maximum frequency, bandwidth) were significantly lower than those in Visayan Hornbill (MannWhitney U test: $P<$ o.001). In the case of temporal parameters, Rufous-headed Hornbill calls were significantly longer (Mann-Whitney U: test: $P<$ o.ooI) than those of Visayan Hornbill and the location of the maximum amplitude did not differ between these species. In the case of Visayan Hornbill, the DFA correctly classified more than $90 \%$ of all calls (Wilks' lambda $=$ 0.0012) and validation procedure assigned $80 \%$ correctly. Five significant canonical functions described more than $97 \%$ of the variation. The first four canonical functions had an eigenvalue $>_{1}$ and described more than $93 \%$ of the variation. The first two functions describing $78 \%$ of variation were plotted against each other in Figure 5.

In Rufous-headed Hornbill, DFA correctly classified more than $89 \%$ of all calls (Wilks' lambda $=0.0285$ ) and validation yielded an average correct assignment of $85 \%$. The analysis generated three significant canonical functions with eigenvalue $>1$, explaining more than $99 \%$ of the variation. The first two functions describing $79 \%$ of the variation were plotted in Figure 6.

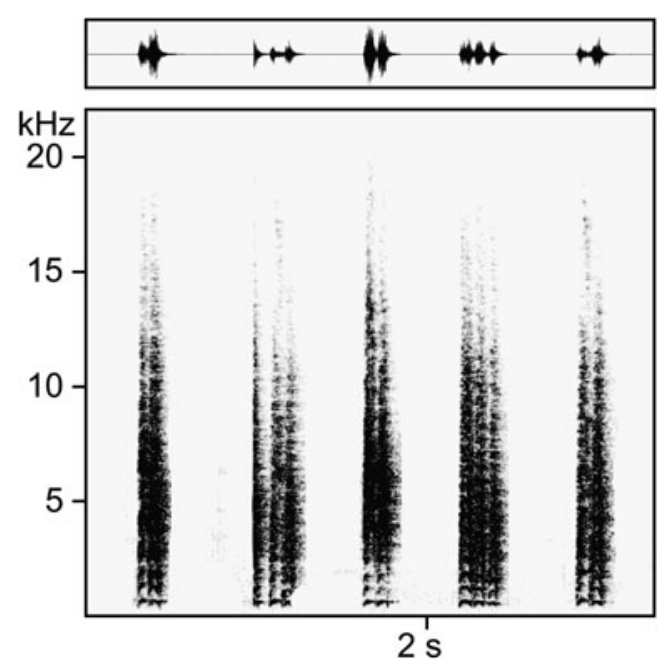

Figure 2. Visayan Hornbill calls which contained two or three elements. 

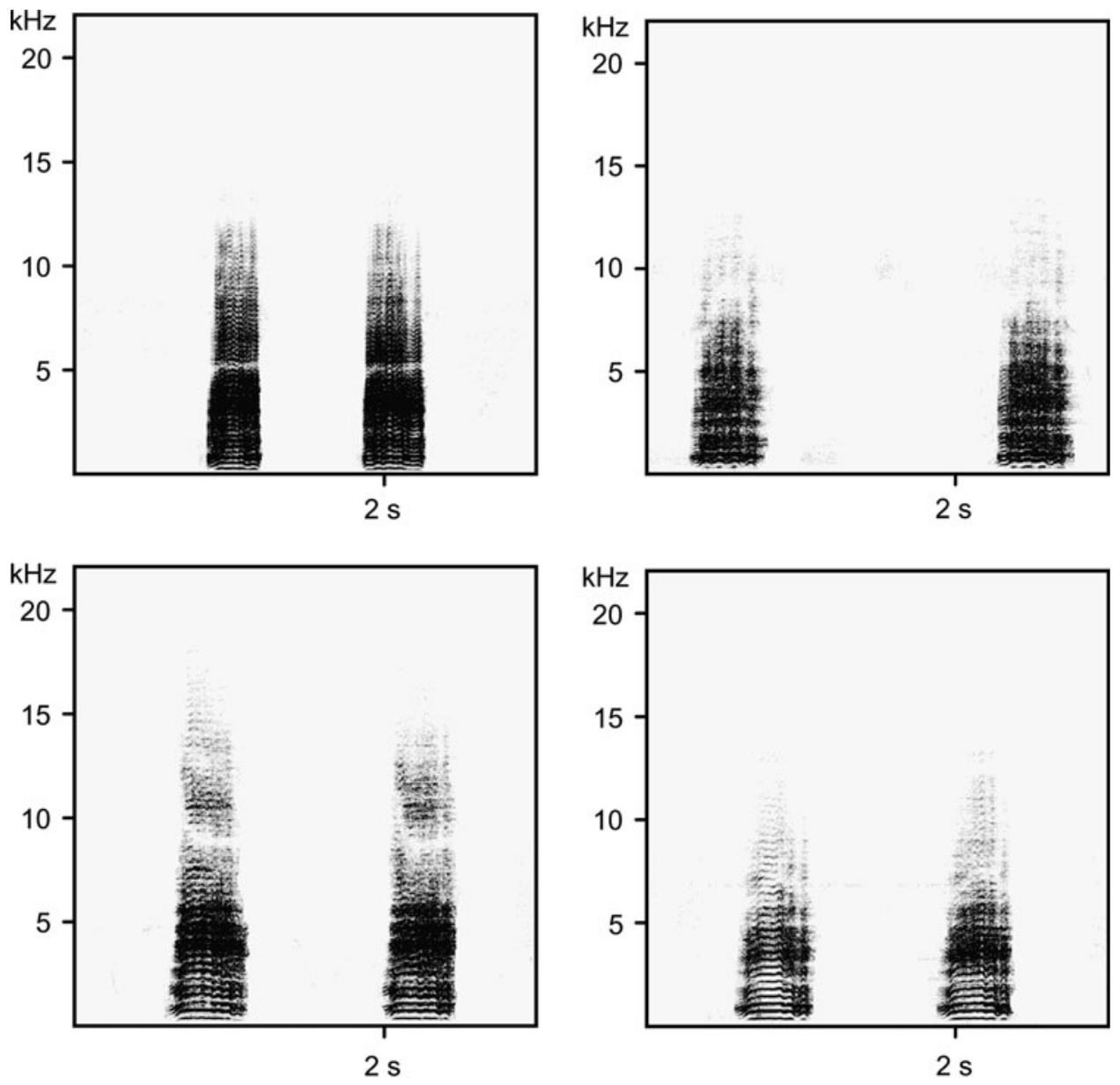

Figure 3. Spectrograms of the Rufous-headed Hornbill calls from four individual males.

For distinguishing among individuals of Visayan Hornbill, the most useful acoustic parameters were second amplitude peak $(r=-0.79)$, time to maximum amplitude in relation to the total call duration $(r=-0.58)$, and call duration $(r=0.46)$ (Table 1$)$. The Kruskal-Wallis ANOVA analysis of the first and second canonical root scores yielded highly significant differences

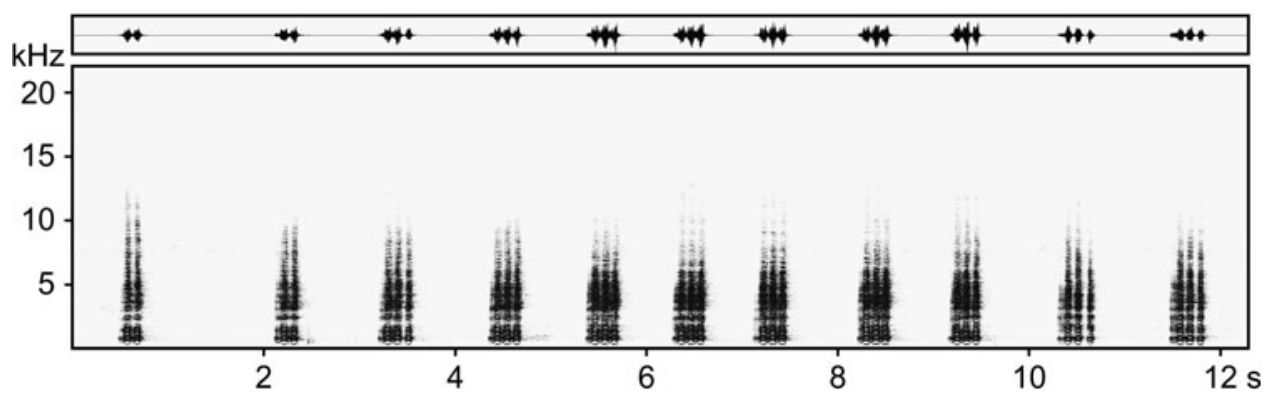

Figure 4. Spectrogram of a typical sequence of Rufous-headed Hornbill calls. 


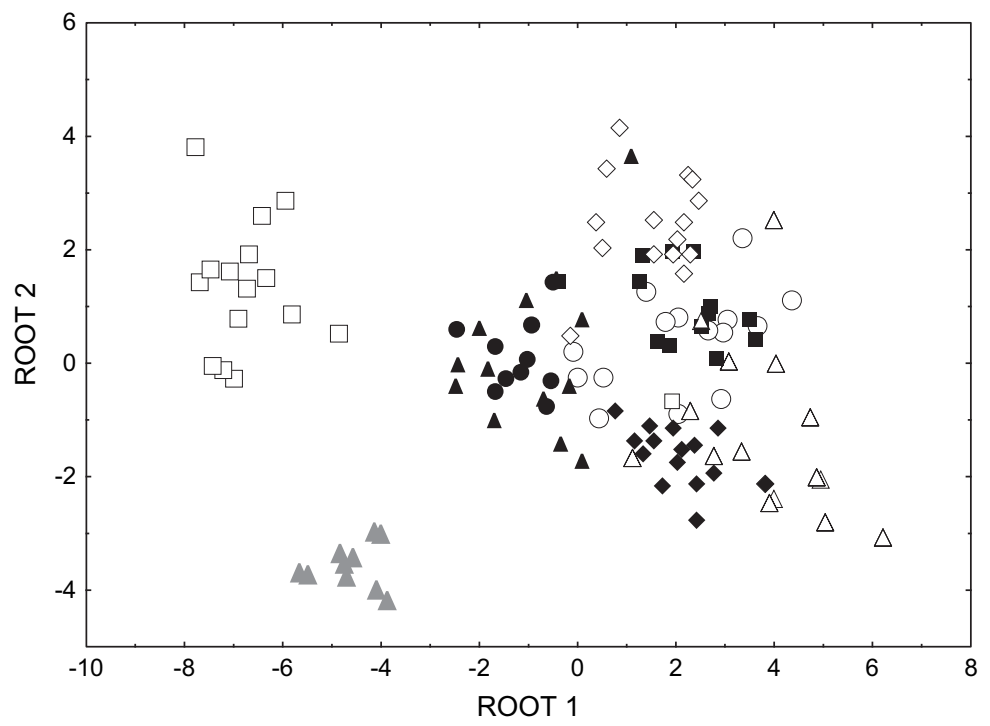

Figure 5. Location of Visayan Hornbill calls from nine males on the first two canonical functions.

between the calls of individual Visayan Hornbill (Root 1 : $H=99.4, P<0.001$; Root 2 : $H=86$, $P<0.001$ ).

For distinguishing between individuals of Rufous-headed Hornbill, the sum of the fundamental and first harmonic frequency $(r=0.65)$ and the upper quartile $(r=0.71)$ were useful (Table 1). The Kruskal-Wallis ANOVA analysis of the first and second canonical root scores

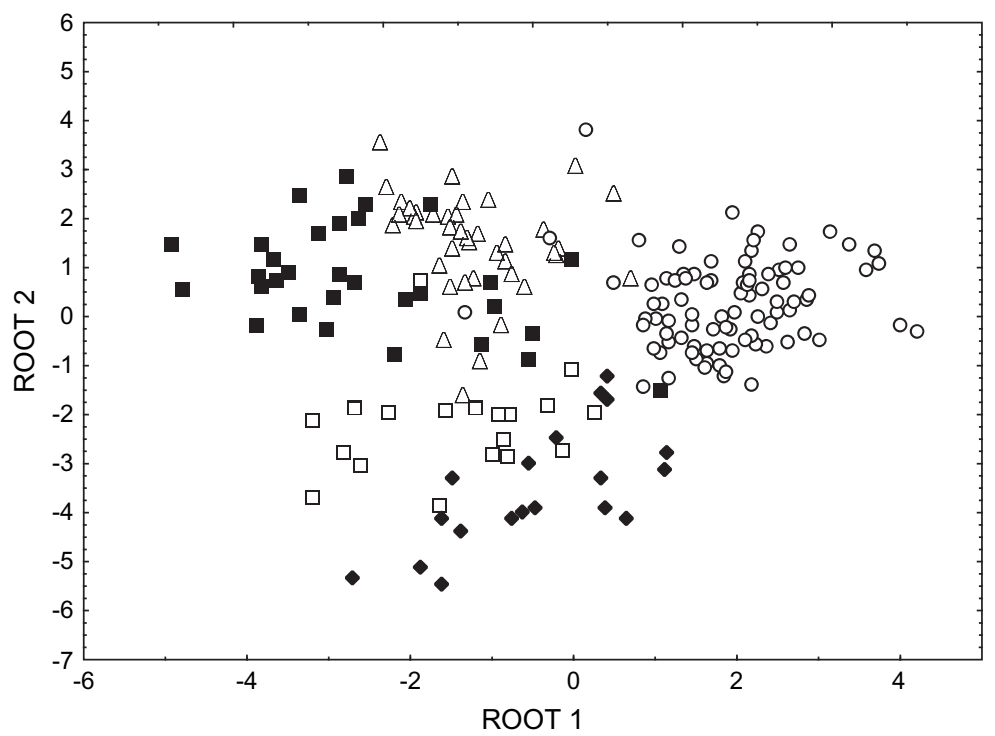

Figure 6. Location of all Rufous-headed Hornbill calls from five males on the first two canonical functions. 
provided highly significant differences between the loud calls of individual Rufous-headed Hornbill (Root 1: $H=149, P<0.001$; Root 2: $H=111, P<0.001$ ).

\section{Discussion}

The present research is the first bioacoustic study of any Philippine hornbill species and the first multivariate analysis of hornbill vocalizations.

In broadband acoustic signals with noisy and atonal structure, where energy is spread over a wide frequency range, it is difficult to decide which parameters should be measured to characterize the properties of a signal (Schrader and Hammerschmidt 1997). Recognition between the animals must be based on a multiparametric analysis, taking into account both spectral and temporal features of the calls (Mathevon 1997). An identification system based on several parameters may better secure vocal signatures and reduce the risk of confusion (Aubin et al. 2007). As such, the multiparametric approach is a very useful technique for analyzing the complex vocalizations of birds (Sparling and Williams 1978, Martindale 1980, Allenbacher et al. 1995, Appleby and Redpath 1996, Böhner and Hammerschmidt 1996, Lengagne 2001).

Our analysis revealed that individuals of the two hornbill species studied can be identified on the basis of their loud calls. This means that hornbill calls contain information about the caller's identity and these findings will also have value for studies of behavioural ecology. Results of correct classification revealed $89 \%$ success in Rufous-headed Hornbill and 90\% success in Visayan Hornbills. These outcomes are comparable with results of other bird species, such as Pygmy Owl Glaucidium passerinum (84\%; Galeotti et al. 1993), Corncrake Crex crex (100\%; Peake et al. 1998), Christmas Island Hawk-Owl Ninox natalis (91\%; Hill and Lill 1998), European Nightjar Caprimulgus europaeus (99\%; Rebbeck et al. 2001), Western Screech-Owl Megascops kennicottii (92\%; Tripp and Otter 2006), European Eagle Owl Bubo bubo (98\%; Grava et al. 2007), and Woodcock Scolopax rusticola (95\%; Hoodless et al. 2008).

The smaller hornbill species, the Visayan Hornbill, has high-pitched calls that are used as contact calls both between mates and other adults. Signals were uttered mostly as single bouts and thus temporal parameters related to spacing of single calls have not influenced vocal individuality. However, some temporal features within single calls such as the time to maximum amplitude and call duration, which were correlated with the second discriminant function, were useful for distinguishing individual Visayan Hornbills. The second discriminant function was correlated with the second amplitude peak. The parameter, time to maximum amplitude, that can be considered a component of amplitude modulation, was important for individual distinctiveness in Visayan Hornbill. This result contrasts with findings in colonial birds where the amplitude modulation is not often used for individual recognition by the birds (Aubin and Jouventin 2002, Jouventin et al. 1999, Charrier et al. 2001, Jouventin and Aubin 2002, Mathevon et al. 2003). In the South Polar Skua Catharacta maccomicki, also, both amplitude and frequency modulation were not good individual markers and individual recognition is based on the spectral profile of their calls (Charrier et al. 2001). The importance of second amplitude peak may reflect the influence of supralaryngeal vocal tract filtration, formant structures, on individual distinction, as has been found in the Whooping Crane Grus americana (Fitch and Kelley 2000) and the Oilbird Steatornis caripensis (Suthers 1994). Based on our results it seems that loud calls of male Visayan Hornbill are not designed for long-distance communication.

On the contrary, in the case of Rufous-headed Hornbill the first discriminant function was correlated with fundamental and first harmonic frequencies, which were significantly lower then those in Visayan Hornbill. Such frequencies are attenuated less rapidly in all types of habitats (Morton 1975, Marten and Marler 1977, Piercy et al. 1977). The second discriminant function was correlated with the upper quartile. The importance of this parameter in discrimination of individuals may indicate the role of whole bandwidth for individual recognition as has been found in parental calls of the Gentoo Penguin Pygoscelis papua (Charrier et al. 2001). Individual identity in loud calls of Rufous-headed Hornbills seems to be encoded in the frequency structure 
of each element of a given call series rather than in temporal parameters related to call series such as the repetition of the elements or call duration. In hornbills, individual distinctiveness of vocalizations has been recorded in the Helmeted Hornbill Rhinoplax vigil (Haimoff 1987) where only the temporal parameter (interval between notes) was observed to be significantly distinct amongst individuals. Individually related differences in spectral parameters are not as commonly recorded as in temporal parameters and they have been found in Whooping Crane (Fitch and Kelley 2000), South Polar Skua (Charrier et al. 2001), Arctic Fox Alopex lagopus (Frommolt et al. 2003), Grey Wolf Canis lupus (Tooze et al. 1990) and Rhesus Macaque Macaca mulatta (Rendall et al. 1998). Frequency parameters in Rufous-headed Hornbill calls were significantly lower than those in Visayan Hornbills.

The differences between these two hornbill species may be caused by different body (van Zyl and Kemp 1998) and casque size (Alexander et al. 1994) or it could also be the result of selection pressure on loud territory calls, when the higher frequency components are lost at long-distance (Wiley and Richards 1982, review in Naguib and Wiley 2001). The Visayan Hornbill, which is the smallest hornbill in the Philippines, has a bill with a low narrow casque (Kennedy et al. 2000) and utters high-pitched calls, while the larger Rufous-headed Hornbill, with a more pronounced casque, has territorial calls with a significantly lower fundamental frequency. Alexander et al. (1994) found a correlation between the casque resonance frequencies and the fundamental frequency. The loud calls of the bigger hornbills indicate existence of amplification and many of them also have a large casque (Kemp 1995). According to our results, in the Rufous-headed Hornbill, which has a more pronounced casque, the fundamental frequency allows discrimination between individuals. In the Visayan Hornbill, with a less pronounced casque, the fundamental frequency did not contribute to individual discrimination and was replaced by other spectral parameters (second amplitude peak) and two temporal parameters (relative location of the maximum amplitude and call duration).

Despite the relatively small sample size, our results show that individually distinctive signatures in hornbill acoustic signals differ significantly between individuals and these findings need to be verified in non-captive situations. It must be emphasized that some other studies (Farquhar 1993, Lengagne 2001, Delport et al. 2002, Grava et al. 2007) have proved bird acoustic individuality based on comparable sample sizes.

Our study demonstrated that the loud calls of hornbills contain some information about the caller. Individual differences in the acoustic structure of the calls are a prerequisite for individual recognition amongst animals (Falls 1982). However, it is necessary to perform playback experiments to verify that animals are using acoustic differences to recognize individuals (Rendall et al. 1996). There is strong evidence that hornbills have high cognitive abilities (e.g. Rasa 1983, Kemp 1995). Rainey et al. (2004b) suggested similarities between the social systems of some hornbills and primates that could lead to the development of sophisticated cognitive abilities. These abilities are directly supported by the existence of hornbill social play and also their large brain (Diamond and Bond 2003). Rainey et al. (2004a) demonstrated that Yellow-casqued Hornbills Ceratogymna elata are able to distinguish between vocalizations of Leopards Panthera pardus and Crowned Eagles Stephanoaetus coronatus as well as between the predator-specific alarm calls of sympatric Diana Monkeys Cercopithecus diana. Similarly, other hornbill species can distinguish between the calls of the two predators (Hauser and Wrangham 1990, Rainey et al. 2004b). Undoubtedly, hornbills have a complex system of communication which needs further investigation.

The role of using vocal individuality as a tool for studying individual animals has been suggested in several studies (Saunders and Wooller 1988, McGregor and Peake 1992, Darden et al. 2003). These techniques may provide less biased data than other marking techniques (Terry et al. 2005). However, the role of DFA in such research purposes is limited (Terry et al. 2001) because of the necessity of knowing the number of individuals, but this limitation may be overcame by using of a non-parametric form of DFA (Terry et al. 2005).

The situation of hornbill conservation in the Philippines is especially urgent (Poonswad and Kemp 1993, BirdLife International 2007a, b, Oliver and Wilkinson 2007). Captive Philippine 
hornbills in breeding centres form reserve populations which may in the future enable reintroductions into the wild. Acoustic signals have the potential to be used for vocal tagging of the reintroduced individuals. Use of acoustic monitoring of individuals, as an alternative non-invasive marking technique, could help in monitoring hornbill individual life history and also in collecting many biological data lacking on Philippine hornbills (see Poonswad and Kemp 1993). Individually distinct vocalizations are especially suitable for monitoring individuals in species sensitive to disturbance caused by capturing and handling (including poaching) and for ethical reasons when capturing can affect survival (De Villiers et al. 1995, Castelli and Trost 1996) and for birds with cryptic behaviour living in the highest forest canopy. Acoustic identification can improve census data and was successfully applied for population censuses of several bird species such as Tawny Owl Strix aluco (Galeotti and Pavan 1991), Great Bittern Botaurus stellaris (Gilbert et al. 2002), Corncrake (Terry \& McGregor 2002), Eagle Owl (Grava et al. 2007), Dupont's Lark Chersophilus duponti (Lailo et al. 2007) and Woodcock (Hoodless et al. 2008). In some cases the information gained from acoustical methods increased the census estimates (Peake and McGregor 2001). Acoustic methods are less time-consuming and have great logistic and welfare advantages over physical capture-recapture methods. But we must keep in mind that acoustic methods are useless for monitoring yearlings in the stage of call development, so each method offers unique information (Lailo et al. 2007). The most effective method for estimating population size or for providing a minimum population size would be capture-mark-recapture technique. This noninvasive method has been used elsewhere by, for example, Eggert et al. (2003) on elephant DNA obtained from dung and by Puechmaille and Petit (2007) on bat DNA and would be equally appropriate for individually distinct hornbill vocalisations when combined with the DFA. If calls were recorded across the study area at regular intervals, it could be possible relatively quickly estimate population size using this technique. Although there is some probability that unknown individual with similar acoustic parameters will be erroneously identified as another one, it does not preclude reliable use of this method. Probability of erroneous identification increases rapidly with the total number of individuals included. This is not a serious problem in extremely rare species and/or populations where the population size does not exceed dozens. Such errors may decrease, but not increase, the estimated population size. Therefore, they make the estimates more conservative.

The loudness and repetitive character of Rufous-headed Hornbill calls are suitable for vocal tagging of individuals in very small fragmented populations and could be useful for tagging individuals born in captivity and introduced into reserves.

It can be expected that the higher frequency calls of very short duration of Visayan Hornbill may be less effective in long-distance transmission and thus less suitable for vocal tagging in the wild. However, this method could be suitable for monitoring birds at their nesting place. A 'voice archive' (see Seymour and Titze 1989) of calls from known individuals would help to re-identify such individuals that were not identified visually (Hartwig 2005).

Individual acoustic variability of bird songs affects reproductive success through male-male competition and mate choice (Catchpole and Slater 1995). Some frequency parameters in nonpasserines may be important for communicating male quality and condition in male-male competition (e.g. Furlow et al. 1998, Mager et al. 2007) and attraction of females (Beani and Dessì-Fulgheri 1995, Appleby and Redpath 1997, Miyazaki and Waas 2003). So the complexity of acoustic characteristics found in loud calls of hornbills may encode information related to mate quality, fitness or health, as well as the individual identity of the caller. Casque resonance frequencies are correlated with the fundamental frequency (Alexander et al. 1994). The lower frequency calls of well developed healthy hornbills with a larger casque may indicate not only greater size and age, but also a better quality of immune system. Also, parameters related to the harshness quality of broadband sounds of hornbill loud calls could signal health status, as found in the ratio of harshness in distress calls of Lesser Short-toed Lark Calandrella rufescens (Lailo et al. 2004), in peak amplitude frequency of harsh syllables in Barn Swallow Hirundo rustica (Garamszegi et al. 2005) or in the total call duration in Tawny Owls (Appleby and Redpath 1997). 
Some head ornaments can serve as indicators of condition in both studied hornbill species (Curio 2004). The relationship of age and parental quality has not been shown for any hornbill species and such ideas await testing for methodological reasons (Curio 2004).

Further studies and playback experiments are needed to understand the dimensions of the information potential of hornbill vocalisations. Individual acoustic variation could reveal a hidden complex signal system in hornbills and a comparative study of vocalisations of the various taxa could provide another area of information to assist in a reassessment of the controversial taxonomy of the species and subspecies of the genus Penelopides.

\section{Acknowledgements}

The study would not be possible without help of many people. We owe a special thanks to William Oliver for his help and support of our research in the Philippines, also to Marisol Pedregosa and Pavel Hospodarský for their help in the initial planning of our project. Thank also to the staff of Mari-it Conservation Park and BCC-FFI. We are grateful to DENR officers for permission to conduct this research. Richard Policht and Milada Petru were supported by Grant Agency of the Czech Republic (No.206/05/Ho12). We thank also Xiao-Yin Zhang, Tristan Farrow and Gareth Bloomfield for language corrections in the early version of this manuscript. The research equipment was funded by the Grant Agency of the Charles University in Prague, project No. B-BIO-185/2004.

\section{References}

Alexander, G. D., Houston, D. C. and Campbell, M. (1994) A possible acoustic function for the casque structure in hornbills (Bucerotidae). J. Zool. 233: 57-67.

Allenbacher, R., Böhner, J. and Hammerschmidt, K. (1995) Individuelle Merkmale im "krah"-Ruf der Nebelkrähe Corvus corone cornix. J. Ornithology 136: 441-446.

Appleby, B. M. and Redpath, S. M. (1996) Variation in the male territorial hoot of the tawny owl Strix aluco in three English populations. Ibis 139: 152-158.

Appleby, B. M. and Redpath, S. M. (1997) Indicators of male quality in the hoots of tawny owls (Strix aluco). J. Raptor Res. 31: 65-70.

Aubin, T. and Jouventin, P. (1998) Cocktailparty effect in king penguin colonies. Proc. R. Soc. Lond. B. 265: 1665-1673.

Aubin, T. and Jouventin, P. (2002) Localisation of an acoustic signal in a noisy environment: the display call of the king penguin Aptenodytes patagonicus. J. Exp. Biol. 205: 3793-3798.

Aubin, T., Mathevon, N., Da Silva, M. L., Vielliard, J. M. E. and Sebe, F. (2004) How a simple and stereotyped acoustic signal transmits individual information: the song of the White-browed Warbler Basileuterus leucoblepharus. Anais da Academia Brasileira de Ciências 76: 335-344.

Aubin, T., Mathevon, N., Staszewski, V. and Boulinier, T. (2007) Acoustic communication in the Kittiwake Rissa tridactyla: potential cues for sexual and individual signatures in long calls. Polar Biol. 30: 1027-1033.

Baker, M. C. (1982) Individuality of vocalizations in Dunlin: a possible acoustic basis for recognition of parent by offspring. Auk 99: 771-774.

Beani, L. and Dessì-Fulgheri, F. (1995) Mate choice in the grey partridge, Perdix perdix: role of physical and behavioural male traits. Anim. Behav. 49: 347-356.

BirdLife International (2007a) Species factsheet: Penelopides panini. http://www.bird life.org on $10 / 4 / 2008$

BirdLife International $(2007 \mathrm{~b})$ Species factsheet: Aceros waldeni. http://www.birdlife. org on $10 / 4 / 2008$

Böhner, J. and Hammerschmidt, K. (1996) Computer-aided acoustic analysis of complex bird calls. Bioacoustics 6: 313-314.

Bradbury, J. W. and Vehrencamp, S. L. (1998) Principles of animal communication. Sunderland, Massachusetts: Sinauer Associates. 
Brooks, T. M., Evans, T. D., Dutson, G. C. L., Anderson, G. Q. A., Asane, D. C., Timmins, R. J. and Toledo, A. G. (1992) The conservation status of the birds of Negros, Philippines. Bird Conserv. Internatn. 2: 273-302.

Castelli, P. M. and Trost, R. E. (1996) Neck bands reduce survival of Canada geese in New Jersey. J. Wildl. Manage. 60: 891-898.

Catchpole, C. K. and Slater, P. J. B. (1995) Bird song: biological themes and variations. Cambridge, UK: Cambridge University Press.

Chapman, C. A. and Lefebvre, L. (1990) Manipulating foraging group size: spider monkey food calls at fruiting trees. Anim. Behav. 39: 891-896.

Charrier, I., Jouventin, P., Mathevon, N. and Aubin, T. (2001) Individual identity coding depends on call type in the South Polar skua Catharacta maccormicki. Polar Biol. 24: 378-382.

Collar, N. J., Mallari, N. A. and Tabaranza, B. A. Jr. (1999) Threatened birds of the Philippines. Manila: Bookmark, Inc.

Curio, E. (2004) On ornamental maturation of two Philippine hornbill species with a note on physiological colour change. J. Ornithol. 145: 227-237.

Darden, S. K., Dabelsteen, T. and Pedersen, S. B. (2003) A potential tool for swift fox (Vulpes velox) conservation: individuality of long-range barking sequences. J. Mammal. 84: 1417-1427.

De Villiers, M. S., Meltzer, D. G. A., van Heerden, J., Mills, M. G. L., Richardson, P. R. K., and van Jaarsveld, A. S. (1995) Handling-induced stress and mortalities in African wild dogs (Lycaon pictus). Proc. $R$. Soc. B. 262: 215-220.

Delport, W., Kemp, A. C. and Ferguson, W. H. (2002) Vocal identification of individual African Wood Owls Strix woodfordii: a technique to monitor long-term adult turnover and residency. Ibis 144: 30-39.

Dhondt, A. A. and Lambrechts, M. M. (1992) Individual voice recognition in birds. Trends Ecol. Evol. 7: 178-179.

Diamond, J. and Bond, A. B. (2003) A comparative analysis of social play in birds. Behaviour 140: 1091-1115.

Eggert, L. S., Eggert, J. A. and Woodruff, D. S. (2003) Estimating population sizes of elusive animals: the forest elephants of Kakum National Park, Ghana. Mol. Ecol. 12: 1389-1402.

Falls, J. B. (1982) Individual recognition by sounds in birds. Pp. $237-278$ in D. E. Kroodsma and E. H. Miller, eds. Acoustic communication in birds. Vol. 2. New York: Academic Press.

Farquhar, C. C. (1993) Individual and intersexual variation in alarm calls of the White-tailed Hawk. Condor 95: 234-239.

Fitch, W. T. and Kelley, J. P. (200o) Perception of vocal tract resonances by whooping cranes (Grus americana). Ethology 106: 559-574.

Frommolt, K. H., Goltsman, M. E. and MacDonald, D. W. (2003) Barking foxes, Alopex lagopus: field experiments in individual recognition in a territorial mammal. Anim. Behav. 65: 509-518.

Furlow, B., Kimball, R. T. and Marshall, M. C. (1998) Are rooster crows honest signals of fighting ability? Auk 115: 763-766.

Galeotti, P. and Pavan, G. (1991) Individual recognition in male tawny owls (Strix aluco) using spectrograms of their territorial calls. Ethol. Ecol. Evol. 3: 113-126.

Galeotti, P., Paladin, M. and Pavan, G. (1993) Individually distinct hooting in male Pygmy Owls Glaucidium passerinum: a multivariate approach. Ornis Scand. 24: 15-20.

Garamszegi, L. Z., Heylen, D., Møller, A. P., Eens, M. and de Lope, F. (2005) Agedependent health status and song characteristics in the barn swallow. Behav. Ecol. 3: 580-591.

Gilbert, G., Tyler, G. A. and Smith, K. W. (2002) Local annual survival of booming male great bittern Botaurus stellaris in Britain, in the period 1990-1999. Ibis 144: 51-61.

Grava, T., Mathevon, N., Place, E. and Balluet, P. (2007) Individual acoustic monitoring of the European Eagle Owl Bubo bubo. Ibis, doi: 10.111 I/j.1474-919x2007.00776.x

Haimoff, E. H. (1987) A spectrographic analysis of the loud calls of helmeted hornbills Rhinoplax vigil. Ibis 129: 319-326.

Hartwig, S. (2005) Individual acoustic identification as a non-invasive conservation tool: an approach to the conservation of the African wild dog Lycaon pictus (Temminck, 1820). Bioacoustics 15: 35-50. 
Hauser, M. D. and Wrangham, R. W. (1990) Recognition of predator and competitor calls in nonhuman primates and birds: a preliminary report. Ethology 86: 116-130.

Hill, R. F. A. and Lill, A. (1998) Vocalisations of the Christmas Island Hawk-Owl Ninox natalis: individual variation in advertisement calls. Emu 98: 221-226.

Hoodless, A. N., Inglis, J. G., Doucet, J. P. and Aebischer, N. (2008) Vocal individuality in the roding calls of Woodcock Scolopax rusticola and their use to validate a survey method. Ibis 150: 80-89.

Jouventin, P. (1982) Visual and vocal signals in penguins, their evolution and adaptive characters. Berlin: Verlag Paul Parey.

Jouventin, P., Aubin, T. and Lengagne, T. (1999) Finding a parent in a king penguin colony: the acoustic system of individual recognition. Anim. Behav. 57: 1175-1183.

Jouventin, P. and Aubin, T. (2002) Acoustic systems are adapted to breeding ecologies: individual recognition in nesting penguins. Anim. Behav. 64: 747-757.

Kauth, M., Engel, S., Lastimoza, L. and Curio, E. (1998) Observations on the breeding biology of the Writhed-billed Hornbill (Aceros waldeni) in the Philippines. J. Ornithol. 139: 475-483.

Kazial, K. A., Burnett, S. C. and Masters, W. M. (2001) Individual and group variation in echolocation calls of big brown bats, Eptesicus fuscus (Chiroptera: Vespertilionidae). J. Mammal. 82: 339-351.

Kemp, A. (1995) Bird families of the world. The hornbills: Bucerotiformes. Oxford: Oxford University Press.

Kemp, A. C. (2001) Family Bucerotidae (Hornbills). Pp. 436-523 in J. del Hoyo, A. Elliott and J. Sargatal, eds. Handbook of the birds of the world. Volume 6 Mousebirds to Hornbills. Barcelona: Lynx Edicions.

Kennedy, R. S., Gonzales, P. C., Dickenson, E. C., Miranda, H. C. Jr. and Fisher, T. (2000) A guide to the birds of the Philippines. Oxford: Oxford University Press.

Klecka, W. R. (1980) Discriminant analysis series: quantitative applications in the social sciences. Beverly Hills, CA: Sage Publications.

Klop, E., Curio, E. and Lastimoza, L. (200o) Breeding biology, nest site characteristics and nest spacing of the Visayan Hornbill Penelopides panini panini on Panay, Philippines. Bird Conserv. Internatn. 10: 17-27.

Lailo, P., Tella, J. L., Carrete, M., Serrano, D. and López, G. (2004) Distress calls may honestly signal bird quality to predators. Proc. R. Soc. B. (Suppl.) 271: S513-S515.

Lailo, P., Vögeli, M., Serrano, D. and Tella, J. L. (2007) Testing acoustic versus physical marking: two complementary methods for individual-based monitoring of elusive species. J. Avian Biol. 38: 672-681.

Lengagne, T. (2001) Temporal stability in the individual features in the calls of eagle owls (Bubo bubo). Behaviour 138: 1407-1419.

Mager, III, J. N., Walcott, C. and Piper, W. H. (2007) Male common loons, Gavia immer, communicate body mass and condition through dominant frequencies of territorial yodels. Anim. Behav. 73: 683-69o.

Marten, K. and Marler, P. (1977) Sound transmission and its significance for animal vocalizations. I. Temperate habitats. Behav. Ecol. Sociobiol. 2: 271-290.

Martindale, S. (1980) On the multivariate analysis of avian vocalizations. J. Theor. Biol. 83: 107-110.

Mathevon, N. (1997) Individuality of contact calls in the greater flamingo Phoenicopterus ruber and the problem of background noise in a colony. Ibis 139: 513-517.

Mathevon, N., Charrier, I. and Jouventin, P. (2003) Potential for individual recognition in acoustic signals: a comparative study of two gulls with different nesting patterns. C. R. Biologies 326: 329-337.

McComb, K., Reby, D., Baker, L., Moss, C. and Sayialel, S. (2003) Long-distance communication of acoustic cues to social identity in African elephants. Anim. Behav. 65: 317-329.

McGregor, P. K. and Peake, T. M. (1992) Individually distinct Bittern booms: potential as a census tool. Bioacoustics 4: 93-109. Mitchell, B. R., Makagon, M. M., Jaeger, M. M. and Barrett, R. H. (2006) Information content of coyote barks and howls. Bioacoustics 15: 289-314.

Miyazaki, M. and Waas, J. R. (2003) Acoustic properties of male advertisement and their impact on female responsiveness in little penguins Eudyptula minor. J. Avian Biol. 34: 229-232. 
Morton, E. S. (1975) Ecological sources of selection on avian sounds. Am. Nat. 109: 17-34.

Naguib, M. and Wiley, R. H. (2001) Estimating the distance to a source of sound: mechanisms and adaptations for long-range communication. Anim. Behav. 62: 825-837.

Oliver, W. L. R. and Wilkinson, R. (2007) Philippine hornbills conservation programme. Pp. 13-30 in A. C. Kempand M. I. Kemp, eds. The active management of hornbills and their habitats for conservation. CD-ROM. Proceedings of the $4^{\text {th }}$ International Hornbill Conference, Mabula Game Lodge, Bela-Bela, South Africa.

Peake, T. M., McGregor, P. K., Smith, K. W., Tyler, G., Gilbert, G. and Green, R. E. (1998) Individuality in Corncrake Crex crex vocalizations. Ibis 140: 120-127.

Peake, T. M. and McGregor, P. K. (2001) Corncrake Crex crex census estimates: a conservation application of vocal individuality. Anim. Biodivers. Conserv. 24: 81-90.

Piercy, J. E., Embelton, T. F. W. and Sutherland, L. C. (1977) Review of noise propagation in the atmosphere. J. Acoust. Soc. Am. 61: 1403-1418.

Poonswad, P. and Kemp, A. C. eds. (1993) Manual to the conservation of Asian hornbills. Bangkok: Faculty of Science, Mahidol University, Hornbill Project.

Puechmaille, S. J. and Petit, E. J. (2007) Empirical evaluation of non-invasive capture-mark-recapture estimation of population size based on a single sampling session. J. Appl. Ecol. 4: 843-852.

Rabor, D. S. (1977) Philippine birds and mammals. Quezon City, Philippines: University of the Philippines Press.

Rainey, H. J., Zuberbühler, K. and Slater, P. J. B. (2004a) Hornbills can distinguish between primate alarm calls. Proc. R. Soc. Lond. B. 271: 755-759.

Rainey, H. J., Zuberbühler, K. and Slater, P. J. B. (2004b) The responses of black-casqued hornbills to predator vocalizations and primate alarm calls. Behaviour 141: 1263-1277.

Rainey, H. J. and Zuberbühler, K. (2007) Seasonal variation in hornbill abundance in a West African national park detected using analysis of acoustic recordings. Bird Conserv. Internatn. 17: 235-244.
Rasa, O. A. E. (1983) Dwarf mongoose and hornbill mutualism in the Taru Desert, Kenya. Behav. Ecol. Sociobiol. 14: 181-190.

Rebbeck, M., Corrick, R., Eaglestone, B. and Stainton, C. (2001) Recognition of individual European Nightjars Caprimulgus europaeus from their song. Ibis 143: 468-475.

Rendall, D., Rodman, P. S. and Emond, R. E. (1996) Vocal recognition of individuals and kin in free-ranging rhesus monkeys. Anim. Behav. 51: 1007-1015.

Rendall, D., Owren, M. J. and Rodman, P. S. (1998) The role of vocal tract filtering in identity cueing in rhesus monkey (Macaca mulatta) vocalizations. J. Acoust. Soc. Am. 103: 602-614.

Ripley, S. D. and Rabor, D. S. (1956) Birds from Canlaon Volcano in the highlands of Negros island in the Philippines. Condor 58: 283-91.

Saunders, D. A. and Wooller, R. D. (1988) Consistent individuality of voice in birds as a management tool. Еmu 88: 25-32.

Schrader, L. and Hammerschmidt, K. (1997) Computer-aided analysis of acoustic parameters in animal vocalizations: a multiparametric approach. Bioacoustics 7: 247-265.

Seymour, S. H. and Titze, I. R. (1989) Audio and sound archives as a resource for voice science: a preliminary report. J. Voice 3: $227-282$.

Sparling, D. W. and Williams, J. D. (1978) Multivariate analysis of avian vocalizations. J. Theor. Biol. 74: 83-107.

Specht, R. (2006) Avisoft-SASLab Pro sound analysis and synthesis laboratory. Berlin: R. Specht.

Steenbeek, R. and Assink, P. (1998) Individual differences in long-distance calls of male Thomas langurs (Presbytis thomasi). Folia Primatol. 69: 77-80.

Steenbeek, R., Assink, P. and Wich, S. A. (1999) Tenure related changes in wild Thomas's langurs II: loud calls. Behaviour 136: 627-650.

Stoddard, P. K. (1996) Vocal recognition of neighbours by territorial passerines. Pp. 356-376 in D. E. Kroodsma and E. H. Miller, eds. Ecology and evolution of acoustic communication in birds. Ithaca, NY: Cornell University Press. 
Sung, H. C. and Miller, E. H. (2007) Variation and individuality in display calls of male Piping Plovers. Condor 109: 468-475.

Suthers, R. A. (1994) Variable asymmetry and resonance in the avian vocal tract: a structural basis for individually distinct vocalizations. J. Compar. Physiol. 175: 457-466.

Terry, A. M. R. and McGregor, P. K. (2002) Census and monitoring based on individually identifiable vocalizations: the role of neural network. Anim. Conserv. 5: 103-111.

Terry, A. M. R., McGregor, P. K. and Peake, T. M. (2001) A comparison of some techniques used to assess vocal individuality. Bioacoustics 11: 169-188.

Terry, A. M. R., Peake, T. M. and McGregor, P. K. (2005) The role of vocal individuality in conservation. Front. Zool. 2: 1-16.

Tooze, Z. J., Harrington, F. H. and Fentress, J. C. (1990) Individually distinct vocalizations in timber wolves. Anim. Behav. 40: 723-740.

Tripp, T. M. and Otter, K. A. (2006) Vocal individuality as a potential long-term monitoring tool for Western Screech-owls, Megascops kennicottii. Can. J. Zool. 84: 744-753. van Zyl, A. J. and Kemp, A. (1998) A comparative study of the loud calls of some Asian hornbills. Thai Studies in Biodiversity 2: 171-180.

Wich, S. A., Assink, P. R., Becher, F. and Sterck, E. H. M. (2002) Playbacks of loud calls to wild Thomas langurs (Primates; Presbytis thomasi): the effect of familiarity. Behaviour 139: 79-87.

Wiley, R. H. and Richards, D. G. (1982) Adaptations for acoustic communications in birds: sound transmission and signal detections. Pp. 131-181 in D. E. Kroodsma and E. H. Miller, eds. Evolution and ecology of acoustic communication in birds. Vol. 1. New York: Academic Press.

Ydenberg, R., Giraldeau, L. and Falls, J. (1988) Neighbours, strangers and the asymmetric war of attrition. Anim. Behav. 36: 343-347.

Yorzinski, J. L., Vehrencamp, S. L., Clark, A. B. and McGowan, K. J. (2006) The inflected alarm caw of the American Crow: Differences in acoustic structure among individuals and sexes. Condor 108 518-529.

\section{RICHARD POLICHT*}

Institute of Tropics and Subtropics, Czech University of Life Sciences Prague, Kamȳycká 129, 16521 Prague 6, Czech Republic and Department of Zoology, Charles University, Viničná 7 , 12844 Prague 2, Czech Republic.

\section{MILADA PETRŮ}

Department of Zoology, Charles University, Viničná 7, 12844 Prague 2, Czech Republic.

\section{LUCIA LASTIMOZA}

Mari-it Conservation Park, West Visayas State University, Lambunao, Panay, Philippines.

\section{LEO SUAREZ \\ Biodiversity Conservation Center, Negros Forests and Ecological Foundation, Inc., Bacolod City, Philippines.}

*Author for correspondence; e-mail: richard.policht@seznam.cz

Received II April 2008; revision accepted 7 July 2008 